\title{
Analysis on Transfer Price Discrimination of Intermediate Product Based on Tax
}

\author{
Chen Shao-gang, Wang Hao-xian \\ School of Mathematical Sciences \\ UESTC \\ Chengdu, China \\ 18200279682@163.com
}

\begin{abstract}
Based on linear demand function of final product market, the paper built a perfect and complete information dynamic game model to analyze the transfer price discrimination in multinational enterprises when the divisions face different tax rates. And then got strategies about transfer price of the enterprises. Based on this, it is concluded that the internal transfer price is lower than the external transfer price and the downstream division will be more competitive in the final product market.
\end{abstract}

Keywords-transfer price; price discrimination; intermediate product; tax

\section{INTRODUCTION}

Transfer pricing is a kind of pricing mechanism which is used to dealing with the resource allocation, benefit distribution and enterprises' specific strategic goal of enterprise groups when dealing with internal or interest related divisions. Hirshleifer had researched the transfer price early and had proved that the necessary condition of maximizing the overall profits of a firm is that the transfer price should be equal with marginal cost of the seller division in [1]. The conclusion also stated that the transfer price should be market price under the condition of a complete competition market. Yin-ping $\mathrm{Mu}$ expanded the conclusion and proved that using price discrimination can be more efficient than uniform pricing in [2] Yu-xian Wang,Yu-Ming Xiao and Sheng Zhong explored the internal transfer pricing method without the external market and established the profit pricing method in the enterprise in [3]. Rong-cuo $\mathrm{Hu}$ and Shao-gang Chen compared different transfer pricing method under Stackelberg competition in final product market in [4] and indicated that pricing discrimination could bring greater benefits to manufacturers. Based on the above-mentioned results, Pfeiffer T, Schiller U and Wagner J built an incomplete competition framework and compares the performance of cost-based transfer pricing method under the certain condition in [5].

The above results were obtained without consideration of the tax rate. However the analysis can be simplified under that specific condition, this is not in consistent with the real market. And the following results were studied with the consideration of the tax rate. Yin-pin Mu gave an explicit overview of the internal transfer pricing with or without consideration of tax rate in [6]. Nielsen had explored the different formula apportionment of the manufacturers with tax rate in [7]. The result indicated that formula apportionment is more efficient than separate accounting.

These researches did not find any literatures on the situation of different tax rates when consulted the information. But in the real market, different subsidiaries face different tax rates in real market since the multinational companies' upstream and downstream subsidiaries are in different countries. This is important for pricing strategies and revenue analysis of multinational enterprises. The aim of this study is to examine the use of price discrimination in the transfer pricing of intermediate product. We introduced that upstream and downstream subsidiaries of multinational companies face different tax rates. The upstream subsidiary monopolizes the production and sale of intermediate products. The downstream subsidiary has a competitive external market in the local final product market. Due to the monopoly of the upstream subsidiary, the downstream subsidiary has a leading position in the final product market. Group headquarters obtain the maximum benefit through the method of price discrimination in transfer pricing and to further analyze the results of the equilibrium, then conclude instructional conclusions for the real market.

\section{MODEL ASSUMPTION}

To facilitate the analysis and design, the following hypothesis would be made :

(1)Assume a multinational enterprise has two subsidiary companies located in two countries which were called country 1 and country 2 respectively in different tax rates.

(2)The upstream subsidiary 1 is a monopoly producer for the intermediate product market. There is an external market called $\mathrm{E}$ in the final product market where the downstream subsidiary is located. The downstream subsidiary 2 and the external market $\mathrm{E}$ must purchase intermediate products from the subsidiary 1 for the production of the final product. The monopolies of the upstream subsidiary makes the subsidiary 2 have long-term leadership in the final product market. The external market $\mathrm{E}$ is a follower. The final product market is the Stackelberg competition model. The final product market is demand-driven, and the demand function for the final product is given by $P=a-b Q(\alpha, \beta>0)$. 
(3)It is also assumed that the multinational enterprises are partially non-central. The output and price of the final product is made by the manager of the downstream subsidiary. The manager's performance is based on the profits of the subsidiary. The price and production of intermediate products are determined by the head office of the group.

(4)In order to simplify the calculation, the study assumed that the ratio of intermediate product to final product is $1: 1$, that is to say, 1 unit per unit of final product needs 1 unit intermediate product. And that the decision maker can get real information about the former firm's price and output. So the game is complete and perfect information dynamic game.

\section{Model SOLUTION}

According to the model assumption, the steps in decisionmaking should be:

Step 1 . Subsidiary 1 sets the transfer price of intermediate products which were sold to subsidiary 2 and external market separately. The price of the intermediate products sold to the two divisions could be different in order to maximization the whole multinational enterprise's income.

Step 2.Subsidiary 2 makes its own output decision in the final market with the consideration of the output decision made by subsidiary 1 . Since the enterprise is non-central, the subsidiary 2 makes output decisions to maximization its own income without the consideration of subsidiary 1 .

Step 3. External market decides the output of final product market after the decisions of subsidiary 1 and subsidiary 2 were observed.

This is a complete and perfect information game model; therefore the problem could be solved by a backward recurrence method. Under the condition of the different tax rates of the two subsidiaries, the after-tax profits of each company are given by:

$$
\begin{aligned}
\pi_{11} & =\left(1-r_{1}\right)\left(P_{1} Q_{1}+P_{2} Q_{2}\right) \\
\pi_{12} & =\left(1-r_{2}\right)\left(P-P_{1}\right) Q_{1} \\
& =\left(1-r_{2}\right)\left(a-b\left(Q_{1}+Q_{2}\right)-P_{1}\right) Q_{1} \\
\pi_{2}= & \left(1-r_{2}\right)\left(P-P_{2}\right) Q_{2} \\
= & \left(1-r_{2}\right)\left(a-b\left(Q_{1}+Q_{2}\right)-P_{2}\right) Q_{2}
\end{aligned}
$$

Where

$$
\begin{aligned}
& \pi_{1 i}: \text { is subsidiary company's total after-tax income } \\
& \pi_{2}: \text { is external market's total after-tax income } \\
& P_{1}: \text { is the transfer price of intermediate product sold to } \\
& \text { downstream subsidiary } 2
\end{aligned}
$$

$P_{2}$ : is the transfer price of intermediate product sold to external market
$P$ : is final product's price

$Q_{1}$ : is the downstream subsidiary 2's output in final product market

$$
\begin{aligned}
& Q_{2} \text { : is the external market's output in final product market } \\
& r_{i} \text { : is the tax rate of country } \mathrm{i}
\end{aligned}
$$

Under the condition of the model, the external market makes decisions under the condition of the transfer price set by subsidiary 1 and the output level of subsidiary 2. That is, the external market's output level equals:

$$
\max _{Q_{2}}\left\{\pi_{2}\right\}=\max \left\{\left(1-r_{2}\right)\left(a-b\left(Q_{1}+Q_{2}\right)-P_{2}\right) Q_{2}\right\}
$$

On the basis of the first order condition of the income maximization, the output level of the external market is satisfied with:

$$
\frac{\partial \pi}{\partial Q_{2}}=\left(1-r_{2}\right)\left(a-b Q_{1}-2 b Q_{2}-P_{2}\right)=0
$$

Hence, solving for (5) we obtain:

$$
Q_{2}=\frac{1}{2 b}\left(a-b Q_{1}-P_{2}\right)
$$

Then downstream subsidiary 2 makes decisions on output level according to the decision of the external market, that is, the reaction function of the external market is available to the subsidiary 2 and the enterprise is non-central. The managers of the subsidiaries make decisions on maximizing the profits of subsidiaries. According to (2) and (6), the output decision of the subsidiary 2 is given by:

$$
\max _{Q_{1}}\left\{\pi_{12}\right\}=\max \left\{\frac{1}{2}\left(1-r_{2}\right)\left(a-b Q_{1}+P_{2}-2 P_{1}\right) Q_{1}\right\}
$$

On the basis of the first condition, the reaction function of external market equals:

$$
Q_{1}=\frac{1}{2 b}\left(a+P_{2}-2 P_{1}\right)
$$

The enterprise sets the transfer prices under the condition of the former results. That is, the enterprise will solve the following optimization problem:

$$
\begin{aligned}
& \max _{P_{1}, P_{2}}\left\{\pi_{1}\right\}=\max \left\{\frac { 1 } { 8 b } \left(2\left(1-r_{1}\right)\left(2 a P_{1}+a P_{2}-4 P_{1}^{2}-3 P_{2}^{2}+4 P_{1} P_{2}\right)\right.\right. \\
& \left.\left.+\left(1-r_{2}\right)\left(a+P_{2}-2 P_{1}\right)^{2}\right)\right\}
\end{aligned}
$$

To obtain the perfect transfer price of enterprise, set $\pi^{\prime}=0$, the solution is given by: 


$$
\left\{\begin{array}{c}
P_{1}=\frac{4\left(1-r_{1}\right)-3\left(1-r_{2}\right)}{8\left(1-r_{1}\right)-4\left(1-r_{2}\right)} a \\
P_{2}=\frac{a}{2}
\end{array}\right.
$$

To simplify calculation, suppose $\alpha=1-r_{1}, \beta=1-r_{2}$, we can find that the perfect transfer price is given by:

$$
\left\{\begin{array}{c}
P_{1}=\frac{4 \alpha-3 \beta}{8 \alpha-4 \beta} a \\
P_{2}=\frac{a}{2}
\end{array}\right.
$$

According to the (11), the total profit of the enterprise and the price of the final product will be:

$$
\begin{gathered}
\pi_{1}=\frac{a}{8 b} \frac{\alpha(6 \alpha+\beta)(\alpha-\beta)}{(2 \alpha-\beta)^{2}} \quad(\alpha>\beta) \\
P=\frac{a}{4} \frac{20 \alpha-12 \beta}{8 \alpha-4 \beta}
\end{gathered}
$$

Here is an explanation of $\alpha>\beta$ in (12). Since the price of the final product is higher than it of the intermediate product, that is:

$$
\begin{aligned}
& P>P_{1} \\
\Leftrightarrow & \frac{a}{4} \frac{20 \alpha-12 \beta}{8 \alpha-4 \beta}>\frac{4 \alpha-3 \beta}{8 \alpha-4 \beta} a \\
\Leftrightarrow & \alpha>0 \\
& P>P_{2} \\
\Leftrightarrow & \frac{a}{4} \frac{20 \alpha-12 \beta}{8 \alpha-4 \beta}>\frac{a}{2} \\
\Leftrightarrow & \alpha>\beta
\end{aligned}
$$

\section{CONCLUSIONS}

Proposition 1 If there is Stackelberg competition in the final product market of a multinational enterprise, the upstream subsidiary should be located in a country with a higher tax rate and the downstream subsidiary should be located in a country with a lower tax rate when considering the different tax rates of the different subsidiaries and the method of price discrimination in transfer pricing. This allows the transfer pricing to reach the optimal price under Nash equilibrium.

Proposition 2 If there is Stackelberg competition in the final product market of a multinational enterprise, the internal transfer price is lower than the external transfer price when considering the tax rate and the transfer pricing of the intermediate product is used for price discrimination.
The reason is that under the condition of the different tax rates of the two subsidiaries and external market, the transfer price to internal subsidiary is $P_{1}$, the transfer price to external market is $P_{2}$. Then we can get that:

$$
\begin{aligned}
P_{1}-P_{2} & =\frac{4\left(1-r_{1}\right)-3\left(1-r_{2}\right)}{8\left(1-r_{1}\right)-4\left(1-r_{2}\right)} a-\frac{a}{2} \\
& =\frac{-\left(1-r_{2}\right)}{8\left(1-r_{1}\right)-4\left(1-r_{2}\right)} a<0
\end{aligned}
$$

The result indicates that the downstream enterprise will have lower production cost than external market when the upstream enterprise dominates the intermediate product market. And it confirms with the state in the real market. Also, the multinational enterprise should set the upstream enterprise in the country which has a low tax rate in the condition of the former assumption.

This paper established a complete and perfect information dynamic game model under the condition that the tax rate of each subsidiary company of multinational enterprises is different. The study researched the problem of the differential transfer pricing of intermediate products in the external market for transnational enterprises in the final product market, and then came to the strategy of group transfer pricing. It was concluded that multinationals have lower internal pricing of intermediate products than external transfer pricing. The conclusion was in consistent with the actual situation. Only when the multinational companies will be located in the upper reaches of the higher tax rates in the country, the downstream enterprises set in the lower tax rate countries, the transfer pricing can achieve the optimal equilibrium price. This would be benefit to the company to obtain greater returns.

\section{REFERENCES}

[1] Hirshleifer J. On the Economics of Transfer Pricing[J]. Journal of Business, 1956, 29(3):172-184.

[2] Yin-Ping M, Xiao-Wo T, Yong-Kai M. Study on the Transfer Pricing of Intermediate Product Existing External Monopoly Markets[J]. Systems Engineering-theory \& Practice, 2003.(In Chinese)

[3] Yu-Xian W, Yu-Ming X, Sheng Z. Price Discrimination and Transfer Priceing in the Integrated Firm[J]. Journal of Management Sciences in China, 2001, 9(6):68-72

[4] Rong-Cuo H, Shao-Gang C. Study on Pricing Strategies of Intermediate Product under Stackelberg Competition in Final Product Market[J]. Journal of Systems \& Management, 2008, 17(4):379-384.(In Chinese)

[5] Pfeiffer T, Schiller U, Wagner J. Cost-based transfer pricing[J]. Review of Accounting Studies, 2011, 16(2):219

[6] Yin-Ping M U, Tang X W,LIU Ying. Review on Study for Transfer Pricing[J]. Journal of Management Sciences in China, 2004, 7(3):8696.(In Chinese)

[7] Nielsen S B, Raimondos-Møller P, Schjelderup G. Formula Apportionment and Transfer Pricing under Oligopolistic Competition[J]. Journal of Public Economic Theory, 2010, 5(2):419-437 